\title{
Perbaikan Mutu Genetik Melalui Sistem Grading Ternak dalam Upaya Menunjang Program Pemuliaan Berbasis Digital
}

\author{
Apri Irianto, Asep Gunawan, Muladno* \\ ${ }^{1}$ Departemen Ilmu Produksi dan Teknologi Peternakan, Fakultas Peternakan IPB \\ Jl. Agatis Kampus IPB Dramaga, Bogor 16680 \\ *Email korespondensi: muladno@gmail.com
}

(Diterima: 13-09-2019; Disetujui:14-12-2019)

\begin{abstract}
ABSTRAK
Pengembangan sapi potong di Indonesia telah berkembang dibeberapa daerah dengan menerapkan teknologi dan inovasi peternakan melalui Sekolah Peternakan Rakyat (SPR). Penelitian ini bertujuan memperbaiki mutu genetik sapi PO melalui seleksi berdasarkan sistem grading untuk pembibitan dan perbanyakan sapi, serta melakukan pemantauan perkembangannya dengan program digitalisasi. Penelitian dilakukan melalui pendataan kuantitatif dan kualitatif dengan sistem wawancara langsung ke para peternak menggunakan kuisioner. Parameter penelitian diantaranya karakteristik eksternal, silsilah sapi, dan ukuran tubuh seperti bobot badan dan lingkar dada. Analisis data menggunakan Analisis Deskriptif dan pendugaan model regresi linier. Hasil penelitian menunjukkan bahwa jumlah sapi di Desa Sekaran lokasi Sekolah Peternakan Rakyat sebanyak 971 ekor dengan populasi terbanyak di dusun Ngantru yaitu sebesar $82 \%$. Sistem perkawinan sapi yang sering diterapkan yaitu kawin suntik (inseminasi buatan) sebesar 94\% dan 6\% dengan perkawinan alami. Produktivitas sapi PO cukup tinggi dengan ukuran lebar dada berkisar 154-165 $\mathrm{cm}$ dan bobot badan berkisar 282$309 \mathrm{~kg}$. Body condition score (BCS) sapi PO berada pada kisaran 2-3 di skala 5. Sistem grading menunjukkan bahwa sapi PO banyak tergolong dalam grade A sebesar 58\%. Sapi PO di Desa Sekaran memiliki potensi yang besar untuk dijadikan sumber bibit dan perbanyakan populasi karena telah memiliki sistem grading yang baik .
\end{abstract}

Kata kunci : Desa Sekaran, digitalisasi, sapi PO, seleksi, sistem grading

\begin{abstract}
The development of beef cattle in Indonesia has developed in several regions by implementing animal husbandry technology and innovation through the Sekolah Peternakan Rakyat (SPR). This study aims to improve the genetic quality of PO cattles through selection based on grading systems for cattle breeding and propagation, as well as monitoring their development with a digitization program. The study was conducted with a direct interview system to farmers using a questionnaire. The research parameters included external characteristics, genealogy of cattle, and body size such as body weight and chest size. Data analysis using descriptive statistic and regression analysis. The results showed that the total of cattle in Sekaran Village was 971 with the largest population in the Ngantru approximately $94 \%$. The cattle mating system were conducted using artificial insemination and naturally bred were $94 \%$ and $6 \%$, respectively. PO cattle productivity is high with chest width measurements from 154-165 cm and body weights from $282-309 \mathrm{~kg}$. The body condition score of PO cattles is in the range of 2-3 on a scale of 5. The grading system shows that many PO cattles were classified in grade A was 58\%. PO cattles in Sekaran Village have great potential to be used as a source animal genetic resources of PO breeding center.
\end{abstract}

Keywords : grading system, digital, PO cattle, Sekaran village, selection 


\section{PENDAHULUAN}

Sapi potong merupakan ternak yang banyak dibudidayakan oleh peternak di banyak daerah di Indonesia. Peternak di Indonesia melakukan pengembangan ternak sapi sebagai sampingan atau tabungan. Sapi merupakan salah satu ternak yang penting dalam pemenuhan kebutuhan protein hewani. Ternak sapi selama ini menjadi penyedia kebutuhan daging merah dan sebagai peringkat tertinggi dalam produksi dan konsumsinya di Indonesia (Wasito, 2005). Pengembangan sapi potong di Indonesia telah berkembang dibeberapa daerah dengan menerapkan teknologi dan inovasi peternakan yang baru dan lebih baik. Salah satu bentuk diseminasi teknologi dan inovasi dilakukan di Sekolah Peternakan Rakyat (SPR) dibawah bimbingan LPPM Institut Pertanian Bogor. Program SPR telah berdiri dibeberapa wilayah di Indonesia dan memberikan dampak positif bagi peternakan rakyat.

SPR Kasiman di Kabupaten Bojonegoro Jawa Timur, memiliki sistem pemeliharaan tradisional dan berpola semi intensif. Kondisi ternak di masing-masing SPR masih digolongkan belum memiliki produktivitas yang baik. Salah satu faktor yang sangat penting dalam pengembangan populasi ternak baik untuk tujuan pembibitan (sapi PO) dan penggemukan (Sapi BX) adalah ketersedian sumber bibit yang baik berdasarkan kualitas genetik yang baik. Klasifikasi grading sapi dengan tujuan pembibitan dan penggemukan perlu diidentifikasi secara detail dan komprehensif, diantaranya melalui seleksi berdasarkan sifat kualitatif dan kuantitatif. Seleksi berdasarkan sifat kualitatif dilakukan dengan cara melihat tampilan luar dari ternak diantaranya warna bulu atau postur tubuh. Seleksi berdasarkan sifat kuantitatif dilakukan dengan cara melakukan pengukuran misalnya penimbangan bobot badan atau pengukuran ukuran tubuh ternak. Setelah identifikasi karakteristik khas dilakukan baik secara kualitatif maupun kuantitatif, sapi diseleksi untuk dijadikan bibit dan dilakukan perbanyakan populasi kedepannya.

Hasil penelitian Gunawan dan Putera (2016) menunjukkan bahwa sapi PO di Kabupaten Bojonegoro memiliki karakteristik yang khas dan terlihat memiliki kondisi kesehatan yang baik. Karakterstik sapi PO yaitu memiiki warna tubuh putih sampai abu-abu, badan besar, dan memiliki gelambir panjang menggantung. Berdasarkan nilai indeks morfometrik sapi PO memiliki indeks kumulatif sebesar yaitu 2,07. Rataan nilai indeks morfometrik ini mengindikasikan jenis sapi PO merupakan sapi tipe pedaging yang baik untuk dikembangkan di lokasi SPR. Keberadaan sistem grading berdasarkan sifat kuantitatif tersebut juga perlu didokumentasikan secara baik dan mudah diakses melalui pencatatan berbasis online, sehingga memudahkan sistem pelacakan dari berbagai tempat. Hal ini akan menjamin program pemuliaan melalui perbaikan mutu genetik ternak PO yang berstandar dan terjamin kualitasnya merupakan kunci dalam pengembangan usaha pembibitan dan penggemukan sapi PO. Penelitian ini bertujuan untuk perbaikan mutu genetik sapi PO melalui seleksi berdasarkan grading atau grade untuk pembibitan dan penggemukan, serta melakukan perbanyakan jumlah bibit sapi PO serta melakukan pengawasan mutu bibit sapi PO di SPR Kasiman Bojonegoro.

\section{MATERI DAN METODE}

\section{Tempat dan Waktu}

Lokasi penelitian dilaksanakan di Desa Sekaran, Kecamatan Kasiman, Kabupaten Bojonegoro, Jawa Timur. Penelitian ini menggunakan metode kualitatif dan kuantitatif dengan melihat data fenotipik ternak berdasarkan kuisioner dan pengukuran lingkar dada untuk pendugaan bobot badan pada sapi indukan peranakan ongole (PO) di Desa Sekaran yakni Dusun Ngantru, Jarkulon, dan Jarwetan. Penelitian dilaksanakan pada bulan Juli-Agustus 2019.

\section{Materi Penelitian}

Sapi yang berhasil di data berjumlah 971 ekor yang terdiri dari beberapa bangsa ternak potong dan dari segi yang berbeda-beda. Sapi di data berdasarkan karakteristik fenotipik, catatan atau rekording dengan beberapa parameter seperti: Informasi tetua, sistem pemeliharaan, bangsa, tanggal lahir, status kepemilikan jumlah anak atau ternak, kondisi ternak saat pengambilan data dan data kuantitatif didapatkan dari parameter ukuran tubuh seperti bobot badan dan lingkar dada. Program pemuliaan dilakukan dengan seleksi indukan sapi PO yang terdapat di Desa Sekaran. Pengukuran data bobot badan dan lingkar dada dilakukan untuk mendapatkan gambaran fenotipik dan kriteria seleksi yang tepat berdasarkan ukuran tubuh. 


\section{Pemantauan Betina Terseleksi berdasarkan Sifat Fenotipik}

Sapi PO betina dikelompokkan berdasarkan rata-rata bobot badan. Minimal bobot badan sapi untuk dijadikan kandidat bibit induk yaitu $290 \mathrm{~kg}$ (Gunawan \& Putera 2016). Sapi diatas angka rata-rata dikategorikan dalam kelompok A, sedangkan dibawah rata-rata di kategori kelas B. Setiap ekor sapi diberi identitas eartag dan catatan produktivitas sifat produksi dan reproduksi induk. Setiap pencatatan data anak dan perkembangannya dari induk kelas $\mathrm{A}$ tersebut akan diinput ke sistem database terintegrasi. Mekanisme penyerahan data, yaitu dari peternak kepada ketua Dewan Perwakilan Pemilik Ternak (DPPT), kemudian dari DPPT diberikan ke Tim Input data terintegrasi.

\section{Analisis Data}

Data dianalisis menggunakan analisis deskriptif untuk menghitung rataan dan standar deviasi karakteristik fenotipik yang dihasilkan. Hasil rataan dijadikan sebagai dasar klasifikasi sapi PO. Analisis statistik deskriptif digunakan untuk menginterpretasikan objek sesuai dengan data yang diperoleh (Best 1982; Sukardi 2004). Data dianalisis menggunakan analisis dekriptif dan model regresi pendugaan bobot badan (BB) didasarkan pada Gunawan \& Putera (2016):

$$
\mathrm{BB}=-205+3,15 \mathrm{LD}
$$

\section{Keterangan:}

$\mathrm{BB}=$ bobot badan $(\mathrm{kg})$

$\mathrm{LD}=$ Lingkar Dada $(\mathrm{cm})$

\section{HASIL DAN PEMBAHASAN}

\section{Kondisi Geografis Desa Sekaran}

Kecamatan Kasiman termasuk wilayah geografis Kabupaten Bojonegoro, terdiri dari 10 desa disebelah Barat pusat pemerintahan Kabupaten Bojonegoro. Luas wilayah 51,91 km² terdiri dari dataran rendah. Kecamatan Kasiman berbatasan langsung dengan beberapa Kecamatan. Sebelah selatan berbatasan dengan kecamatan Padangan, sebelah barat Kecamatan Cepu Kabupaten Blora, sebelah utara Kecamatan Kadewan dan sebelah timur Kecamamatan Malo (BPS Kab. Bojonegoro 2018).

Desa Sekaran merupakan salah satu Desa yang berada di Kecamatan Kasiman, Kabupaten Bojonegoro, Jawa Timur. Desa ini terdiri dari 3 Dusun, yaitu Ngantru, Jarkulon, dan Jarwetan yang memiliki potensi pengembangan peternakan rakyat. Desa Sekaran berbatasan langsung dengan Desa Tambak Merak di sebelah utara Desa Besah sebelah selatan Desa Sidomukti sebelah timur dan Desa Kasiman sebelah barat. Suhu di Desa Sekaran berada pada kisaran $28^{\circ} \mathrm{C}$. Luas wilayah Desa Sekaran berdasarkan data yang diperoleh seluas 1.689,5 ha (DPMD 2018).

\section{Jumlah Kepemilikan Ternak}

Kepemilikan ternak di Desa Sekaran cukup banyak dari total keseluruhan Desa yang ada di Kecamatan Kasiman.. Jumlah keseluruhan berdasarkan kepemilikan yakni 971 ekor sapi (Tabel 1). Peternak di Desa Sekaran memelihara sapi sebagai sampingan atau tabungan dengan jumlah ternak yang dimiliki rata-rata antara 1-5 ekor per peternak. Roessali (2004) menyatakan bahwa peternak skala kecil dalam pemeliharaan hanya sebagai sampingan dan cenderung mempertahankan jumlahnya agar tetap sama dari tahun ke tahun berdasarkan kemampuan. Jumlah tersebut masih di kategorikan sebagai usaha peternakan skala kecil. Skala kepemilikan sapi potong petani peternak yang berstatus sebagai peternakan rakyat, dikelompokkan menjadi 3 bagian yaitu skala kecil (1-5 ekor), skala menengah (6-10 ekor) dan skala besar (>10 ekor).

Tabel 1. Jumlah Kepemilikan Ternak di Desa Sekaran

\begin{tabular}{|c|c|c|c|c|c|c|c|}
\hline \multirow{2}{*}{ Dusun } & \multicolumn{5}{|c|}{ Jumlah Kepemilikan } & \multirow{2}{*}{ Total } & \multirow{2}{*}{$\%$} \\
\hline & Jantan & Induk & Dara & Pedet (Jantan) & Pedet (Betina) & & \\
\hline Dusun Ngantru & 62 & 331 & 91 & 67 & 90 & 641 & 66 \\
\hline Dusun Jarkulon & 6 & 87 & 22 & 24 & 28 & 167 & 17 \\
\hline Dusun Jarwetan & 8 & 83 & 27 & 19 & 26 & 163 & 17 \\
\hline Total Ternak & 76 & 501 & 140 & 110 & 144 & 971 & 100 \\
\hline
\end{tabular}




\section{Status Kepemilikan Ternak}

Status kepemilikan ternak dibagi atas 3 kategori yaitu kepemilikan sendiri, kelompok dan gaduhan dengan persentase masing-masing $79,39 \%, 14,34 \%$ dan 6,26\% (Tabel 2). Data tersebut menunjukan bahwa status kepemilikan sendiri memiliki presentase lebih tinggi dibandingkan dengan status kepemilikan kelompok dan gaduhan. Hal tersebut menunjukan bahwa peternak di Desa Sekaran cenderung menggunakan modal sendiri untuk mengembangkan peternakan rakyat. Status kepemilikan kelompok yang ada di Desa Sekaran keberadaannya berdasarkan Sekolah Peternakan Rakyat (SPR) yang bekerajsama antara Australia dan Indonesia IACCB dalam bidang pemuliaan untuk mengembangkan sapi Brahman cross (BX). Gaduhan atau biasa disebut dengan sistem bagi hasil dilakukan oleh peternak yang memiliki modal banyak namun tidak memiliki waktu dan tempat untuk melakukan pengembangan ternak sapi. Sistem pembagian hasil dapat dilakukan dengan cara membagi anakan yang lahir dari indukan yang dipelihara oleh peternak. Hal ini senada dengan hasil penelitian Yulianto \& Cahyo (2010) bila gaduhan sampai sapi beranak, maka anak sapi yang pertama untuk penggaduh dan anak sapi kedua untuk pemilik modal.

Sapi potong menjadi ternak tabungan yang sewaktu-waktu dapat dijual ketika peternak membutuhkan dana untuk memenuhi kebutuhan lainnya sehingga kepemilikan ternak dapat berubah sesuai dengan kondisi. Usaha budidaya sapi saat ini pada umumnya bersifat sampingan (subsistein) dan dilakukan secara tradisional karena hanya sebagai sumber pendapatan sampingan atau hubungan yang dapat menjadi "Emergency Cash" pada saat diperlukan (Wiradarya 2004).

\section{Body Condition Score (BCS)}

Sapi indukan PO di Desa Sekaran paling banyak memiliki BCS 3 dengan persentasi $44,04 \%$ dan yang paling sedikit BCS 5 dengan persentasi 1,15\% (Tabel 3). Hasil penilaian ini sejalan dengan BCS sapi PO dan persilangannya yang dilaporkan oleh Pawere et al. (2012) yang memiliki rata-rata $\mathrm{BCS}$ 2-3. Berdasarkan nilai BCS yang diperoleh, rata-rata sapi PO di Desa Sekaran layak dijadikan sapi bakalan. Nilai BCS sapi bakalan yang baik untuk digemukkan yaitu 2,5 (kurus) - 3 (sedang) (OFAC 2010).

Body condition score sapi PO di Desa Sekaran disajikan pada Tabel 3. Keberhasilan pengembangan peternakan BCS sangat penting untuk diketahui sebagai bahan untuk memberikan nilai pada ternak. BCS juga mampu sebagai bahan kajian yang dapat dikaitkan dengan kondisi ternak baik dari segi produksi maupun reproduksi. Menurut Wildman et al. (1982) sapi memiliki skor 1 adalah sangat kurus yaitu bila processus spinosus pendek tampak jelas, menonjol, dan dapat diraba. Tuber coxae dan Tuber ischiadicus sangat jelas terlihat. Pangkal ekor (anus) kedalam/menyusut, vulva menonjol. Sebaliknya, sapi dengan skor 5 atau sangat gemuk yaitu bila struktur tulang bagian atas Tuber coxae, Tuber ischiadicus.

Tabel 2. Ternak di Desa Sekaran berdasarkan status kepemilikan

\begin{tabular}{lcccccccc}
\hline \multirow{2}{*}{ Kepemilikan } & \multicolumn{2}{c}{ Dusun Ngantru } & \multicolumn{2}{c}{ Dusun Jarkulon } & \multicolumn{2}{c}{ Dusun Jarwetan } & \multirow{2}{*}{ Total } & $\%$ \\
\cline { 2 - 6 } & Jumlah & $\%$ & Jumlah & $\%$ & Jumlah & $\%$ & & \\
\hline Sendiri & 183 & $73 \%$ & 81 & $94 \%$ & 70 & $88 \%$ & 334 & 77 \\
Kelompok & 71 & $22 \%$ & 0 & $0 \%$ & 0 & $0 \%$ & 71 & 16 \\
Gaduhan & 16 & $5 \%$ & 5 & $6 \%$ & 10 & $12 \%$ & 31 & 7 \\
\hline
\end{tabular}

Tabel 3. Kondisi Indukan dengan melihat BCS di Desa Sekaran

\begin{tabular}{ccccccccc}
\hline \multirow{2}{*}{ BCS } & \multicolumn{2}{c}{ Dusun Ngantru } & \multicolumn{2}{c}{ Dusun Jarkulon } & \multicolumn{2}{c}{ Dusun Jarwetan } & \multirow{2}{*}{ Total } & \multirow{2}{*}{$\%$} \\
\cline { 2 - 7 } & Jumlah & $\%$ & Jumlah & $\%$ & Jumlah & $\%$ & & \\
\hline 1 & 54 & $20 \%$ & 8 & $9 \%$ & 14 & $17 \%$ & 76 & 17 \\
2 & 86 & $32 \%$ & 23 & $26 \%$ & 22 & $27 \%$ & 131 & 30 \\
3 & 108 & $41 \%$ & 46 & $53 \%$ & 38 & $46 \%$ & 192 & 44 \\
4 & 15 & $6 \%$ & 9 & $10 \%$ & 8 & $10 \%$ & 32 & 7 \\
5 & 3 & $1 \%$ & 1 & $1 \%$ & 1 & $1 \%$ & 5 & 1 \\
\hline
\end{tabular}




\section{Sistem Perkawinan}

Sistem perkawinan sapi PO di Desa Sekaran dominan menggunakan inseminasi buatan (kawin suntik) dengan persentasi $94 \%$ dan kawin alam 6\% (Tabel 4). Hal ini sesuai dengan penelitian Rosikh et al. (2015) yang menyatakan bahwa inseminasi buatan lebih sering dilakukan oleh para peternak. Sebanyak $72,3 \%$ sapi potong di Kabupaten Gresik dikawinkan dengan sistem inseminasi buatan. Persepsi peternak terhadap IB sangat baik. Hasil penelitian yang dilakukan oleh Alim dan Nurlina (2011) bahwa sebagian besar peternak $(62,50 \%)$ dalam penelitiannya menyatakan bahwa menggunakan inseminasi buatan lebih baik daripada menggunakan pejantan/kawin alami. Inseminasi buatan yang dilakukan di Desa Sekaran bekerjasama dengan Puskeswan. Sistem perkawinan IB memiliki kelebihan, yaitu adanya pencatatan yang dapat dipantau berdasarkan semen yang disuntikkan pada ternak. Sistem IB juga mampu meminimalisir terjadinya inbreeding pada populasi. Program tersebut baik sebagai informasi awal untuk memberikan data yang lengkap mengenai sistem perkawinan dan keberhasilan reproduksi ternak.

\section{Indukan yang di Rekomendasikan dalam Program Digitalisasi Indukan}

Rataan lingkar dada tertinggi pada penelitian ini didominasi oleh Dusun Jarkulon dengan nilai sebesar $163 \pm 9,59 \mathrm{~cm}$. Rataan dan standar deviasi produktivitas ternak (lingkar dada dan bobot badan) indukan di Desa Sekaran disajikan pada Tabel 5. Rataan lingkar dada pada penelitian ini lebih besar dari penelitian sebelumnya yang dilaporkan Gunawan \& Putera (2016) yaitu sapi PO dengan lingkar dada sebesar 156,97 $\pm 1,2 \mathrm{~cm}$, sedangkan Haryoko dan Suparman (2009) melaporkan nilai lingkar dada pada sapi PO sebesar 159,43 $\pm 10,81 \mathrm{~cm}$. Lingkar dada dapat dijadikan acuan untuk menduga bobot badan pada indukan sapi terutama di daerah pedesaan dengan keterbatasan fasilitas (Gunawan \& Putera 2016).

Rataan bobot badan indukan tertinggi di Desa Sekaran masih didominasi oleh Dusun Jarkulon dengan nilai sebesar $309 \pm 30,21 \mathrm{~kg}$. Rataan ukuran lingkar dada sapi PO ini masih relatif lebih tinggi dibandingkan dengan sapi lokal Indonesia lainnya. Putra et al. (2014) melaporkan bahwa rataan bobot badan sapi Aceh sebesar 127,55 $\pm 34,21 \mathrm{~kg}$. Bobot badan sapi PO yang dilaporkan oleh Gunawan \& Putera (2016) memiliki nilai sebesar 289,23 $\pm 1,37 \mathrm{~kg}$. Vergara et al. (2009) melaporkan bahwa bobot badan yang tinggi dapat mempermudah untuk bibit pengganti serta pembiayaan yang lebih efisien dan memungkinkan tercapainya masa hidup yang panjang. Bobot badan yang berbeda antara hasil penelitian dengan literatur dapat disebabkan breed atau bangsa serta lingkungan yang berbeda (Jurado et al., 1994).

Tabel 4. Sistem Perkawinan Indukan di Desa Sekaran

\begin{tabular}{lcccccccc}
\hline \multirow{2}{*}{$\begin{array}{c}\text { Sistem } \\
\text { Perkawinan }\end{array}$} & \multicolumn{2}{c}{ Dusun Ngantru } & \multicolumn{2}{c}{ Dusun Jarkulon } & \multicolumn{2}{c}{ Dusun Jarwetan } & \multirow{2}{*}{ Total } & $\%$ \\
\cline { 2 - 7 } IB & Jumlah & $\%$ & Jumlah & $\%$ & Jumlah & $\%$ & & \\
Alam & 238 & $89 \%$ & 87 & $100 \%$ & 83 & $100 \%$ & 408 & 94 \\
\hline
\end{tabular}

Tabel 5. Data indukan yang direkomendasikan untuk program digitalisasi

\begin{tabular}{lccccc}
\hline \multirow{2}{*}{ Dusun } & \multicolumn{3}{c}{ Umur } & \multicolumn{2}{c}{ Produktivitas Ternak $(\mu \pm$ SD $)$} \\
\cline { 2 - 6 } & Hari & Bulan & Tahun & LD $(\mathrm{cm})$ & BB $(\mathrm{kg})$ \\
\hline Jarwetan & 2103 & 70 & 6 & $154 \pm 10,73$ & $282 \pm 33,79$ \\
Jarkulon & 2040 & 68 & 5.7 & $163 \pm 9,59$ & $309 \pm 30,21$ \\
Ngantru & 2449 & 82 & 7 & $158 \pm 11,74$ & $293 \pm 36,99$ \\
\hline
\end{tabular}

Tabel 6. Data indukan berdasarkan sistem grading di Desa Sekaran

\begin{tabular}{ccccc}
\hline Ranking & Dusun Ngantru & Dusun Jarkulon & Dusun Jarwetan & $\%$ \\
\hline Grade A & 87 & 11 & 12 & 58 \\
Grade B & 62 & 4 & 5 & 37 \\
Grade C & 7 & 0 & 2 & 5 \\
\hline Total & 156 & 15 & 19 & $190 / 100$ \\
\hline
\end{tabular}




\section{Jumlah Indukan Sapi PO Berdasarkan Grade}

Hasil identifikasi grade indukan di Desa Sekaran didominasi oleh indukan grade $A$ berjumlah 110 ekor dengan persentasi 58\%. Data grade $\mathrm{B}$ dan $\mathrm{C}, 71$ dan 9 ekor dengan persentasi 37 dan 5\% (Tabel. 6 ). Grade indukan sapi PO yang berhasil diklasifikasikan dengan grade A adalah indukan yang digunakan sebagai pencetak bibit unggul untuk di imbangi dengan pejantan yang unggul atau semen yang baik, grade B berdasarkan indukan yang direkomendasikan sebagai indukan khusus yang dikembangkan dalam pengembangan bibit ternak potong (bukan bibit unggul), dan yang terakhir adalah grade C. Grade C merupakan grade paling rendah dalam sistem grading kali ini. Grade tersebut mengartikan bahwa indukan yang termasuk grade ini telah masuk umur tua atau majir sehingga dapat direkomendasikan keluar dari populasi. Kondisi data tersebut menandakan bahwa indukan sapi di Desa Sekaran terutama di Dusun Ngantru memiliki potensi yang baik sebagai sumber sapi pembibit di Kabupaten Bojonegoro khususnya daerah Jawa Timur. Faktor lain yang dapat dijadikan sebagai pertimbangan sapi perbibitan adalah kondisi reproduksi sapi yang dilihat berdasarkan jarak beranak, umur sapi dara saat dikawinkan, waktu dikawinkan setelah beranak, umur pedet sapih, umur induk afkir, dan fasilitas untuk inseminasi buatan (Soekardono et al., 2009).

\section{KESIMPULAN}

Sistem grading sapi yang telah dilakukan secara umum dikategorikan grade A dengan proporsi sebanyak $58 \%$ dari total populasi sapi PO. Kategori grade B dan C yang didapatkan masing-masing sebanyak $37 \%$ dan $5 \%$. Perbaikkan mutu genetik sapi PO melalui sistem grading memiliki potensi yang baik untuk dijadikan sumber bibit dan usaha penggemukan dalam perbanyakan populasi mengacu pada kriteria grade yang telah ditentukan..

\section{UCAPAN TERIMA KASIH}

Ucapan terima kasih kepada Kementrian Riset Teknologi dan Pendidikan Tinggi (Kemenristekdikti) yang telah membiayai penelitian terapan unggulan perguruan tinggi melalui proyek: Kode/Nama Rumpun Ilmu: 211/Ilmu Peternakan. Bidang Fokus: Pangan dan Pertanian.

\section{DAFTAR PUSTAKA}

Alim, S. \& L. Nurlina. 2007. Hubungan antara karakteristik dengan persepsi peternak sapi potong terhadap inseminasi buatan. Jurnal Ilmu Ternak 7(2):165-169.

[BPS] Badan Pusat Statistik. 2018. Kecamatan Kasiman dalam Angka. Badan Pusat Statistika. Bojonegoro.

[DPMD] Dinas Pemberdayaan Masyarakat dan Desa. 2018. Potensi dan Tingkat Perkembangan Desa. DPMD Kabupaten Bojonegoro. Bojonegoro.

Gunawan A \& B.W. Putera. 2016. Aplikasi linier ukuran tubuh untuk seleksi fenotipik bibit induk sapi PO di Kabupaten Bojonegoro. Jurnal IPTHP 4(3):375-378.

Haryoko, I. \& P. Suparman. 2009. Evaluation of carcass production of $\mathrm{PO}$ cattle based on heart grith measurement, body condition score and slaughter weight. Animal Production 11(1):28-33.

Jurado, J.J., A. Alonso. \& R. Alenda. 1994. Selection responses for growth in Spanish Merino flock. J. Anim. Sci. 72:1433-1440.

[OFAC] Ontario Farm Animal Council. 2010. Body conditioning score of beef cattle. http://www.ofac.org/pdf/body\%20conditi on\%20score.pdf. [2nd Aug 2019].

Pawere, F.R., E. Baliarti, \& S. Nurtini. 2012. Proporsi bangsa, umur, bobot badan awal dan skor kondisi tubuh sapi bakalan pada usaha penggemukan. Buletin Peternakan 36(3):193-198.

Putra, W.P.B., Sumadi, \& T. Hartatik. 2014. Pendugaan bobot badan pada sapi Aceh dewasa menggunakan dimensi ukuran tubuh. JITP 3(2):76-80.

Roessali, W. 2004. Profitabilitas usaha pembibitan simental di Kecamatan IV Candung Kabupaten Agam. Jurnal Pengembangan Peternakan Tropis. Spesial Edition Seminar Nasional Ruminansia 7 Oktober 2004 Buku 3. Fakultas Peternakan Universitas Diponegoro. Semarang.

Rosikh, A., H.A. Aria, \& M. Qomaruddin. 2015. Analisis perbandingan angka calving rate sapi potong antara kawin alami dengan inseminasi buatan di kecamatan dukun 
kabupaten gresik. Jurnal Ternak 6(1):1317.

Soekardono, A. Chairussyhur, \& L.M. Kasip. 2009. Identifikasi grade sapi bali betina bibit dan koefisien reproduksi sapi betina di Provinsi Nusa Tenggara Barat. Buletin Peternakan 33(2):74-80.

Sukardi. 2004. Metodologi Penelitian Pendidikan: Kompetensi dan Praktiknya. Bumi Aksara. Jakarta.

Vergara, O.D, M.A. Elzo, M.F. Ceron-Munoz, \& E.M. Arboleda. 2009. Weaning weight and post weaning gain genetic parameters and genetic trends in Blanco OrejinegroRomosinuano-Angus-Zebu multibreed cattle population in Columbia. Livestock Science 124:156-162.
Wasito, H.R. 2005. Peternakan Harus Jadi Unggulan. Penerbit Permata Wacana Lestari. Jakarta.

Wildman, E.E, G.M. Jones, P.E. Wagner, R.L. Bowman, H.F. Troutt, \& T.N. Lesch. 1982. A dairy cow body condition scoring system and its relationship to selected production characteristic. J. Dairy Sci. 65: 495.

Wiradarya, T.R. 2004. Peningkatan produktivitas ternak domba melalui perbaikan nutrisi rumput lapang. Laporan Penelitian. Institut Pertanian Bogor. Bogor.

Yulianto, P. \& S. Cahyo. 2010. Pembesaran Sapi Potong secara Intensif. Penebar Swadaya. Jakarta. 